\title{
FACTORS INFLUENCING NURSES' COMPLIANCE WITH PATIENT SAFETY POLICIES IN HOSPITAL
}

\author{
Yuni Dwi Hastuti ${ }^{1 *}$, Shofa Chasani ${ }^{2}$, M. Hasib Ardani ${ }^{3}$ \\ ${ }^{1}$ Division of Adult Nursing, Department of Nursing, Faculty of Medicine, Diponegoro University, Indonesia \\ ${ }^{2}$ Sub-Division of Kidney Hypertension, Internal Medicine Program, Faculty of Medicine, Diponegoro Uni- \\ versity, Indonesia \\ ${ }^{3}$ Division of Basic Nursing and Fundamentals of Nursing, Department of Nursing, Faculty of Medicine, \\ Diponegoro University, Indonesia \\ *e-mail: yuni.dh@fk.undip.ac.id
}

\begin{tabular}{|c|c|}
\hline & ABSTRACT \\
\hline $\begin{array}{l}\text { Keywords: } \\
\text { hospital policies } \\
\text { nurses' compliance } \\
\text { patient safety }\end{array}$ & $\begin{array}{l}\text { Patient safety is a global issue and a top priority in hospitals. Incidence of unexpected } \\
\text { events varies significantly in Indonesia. Nurses' compliance is an essential factor in the } \\
\text { successful implementation of patient safety policies in hospitals. This study aimed to } \\
\text { determine the factors influencing nurses' compliance with patient safety policies in inpa- } \\
\text { tient units of Dr. Kariadi general hospital, Semarang. This study employed a descriptive } \\
\text { correlational design with a cross-sectional approach. The samples were } 220 \text { staff nurses } \\
\text { recruited using a proportional random sampling technique. The data were collected using } \\
\text { a questionnaire developed by the researchers and analyzed using the univariate analysis, } \\
\text { Chi-square test, and multivariate multiple logistic regression test. Results of the bivariate } \\
\text { analysis showed that there were effects of supervision ( } \mathrm{p}=0.038 \text {; OR }=1.828 \text { ), the } \\
\text { character of authority figures ( } \mathrm{p}=0.001 \text {; OR }=2.648) \text {, and non-compliant colleagues (p } \\
=0.0001 \text {; OR }=2.899 \text { ) on nurses' compliance with patient safety policies. However, } \\
\text { gender ( } \mathrm{p}=0.691 \text { ), working environment ( } \mathrm{p}=0.891) \text {, and contradictory orders ( } \mathrm{p}= \\
0.243 \text { ) were found to have no effects on nurses' compliance with patient safety policies. } \\
\text { Results of multivariate analysis using a multiple logistic regression analysis showed that } \\
\text { non-compliant colleagues were the most influential factor of nurses' compliance with } \\
\text { patient safety policies in the hospital. There were effects of supervision, the character of } \\
\text { authority figures, and non-compliant colleagues on nurses' compliance with patient safety } \\
\text { policies. In contrast, gender, working environment, and contradictory orders showed no } \\
\text { effects on nurses' compliance. Non-compliant colleagues had the most effect on nurses' } \\
\text { compliance. }\end{array}$ \\
\hline
\end{tabular}

\section{BACKGROUND}

Safety has become a global issue in all sectors, including hospitals. Safety is a top priority to be implemented in the hospital and is related to the quality and image of the hospital itself (Rochmanadji, 2009). Patient safety is a system that requires policies to regulate standards and guidelines for its implementation in the form of national and internal hospital policies (Rochmanadji, 2009; Pudjirahardjo, 2006). The successful implementation of such policies is deter- mined mainly by the role of all individuals in the hospital, one of which is nurses as health workers who have a high interaction time with patients (Sudarma, 2008). The role of nurses in the implementation of hospital policies is reflected in their compliant behaviors towards these policies.

There are some theories of compliance, one of which is developed by Stanley Milgram, a psychologist who conducted experiments on compliant behaviors. Milgram, based on the variety of research that he had conducted, explained that there are some 
factors influencing compliance, including gender, supervision, working environment, the character of authority figures, contradictory orders, and non-compliant colleagues (Milgram, 1974). Such factors may further affect nurses' compliance with patient safety policies in the hospital.

The purpose of this study was to analyze the factors influencing nurses' compliance with patient safety policies in the inpatient units of Dr. Kariadi hospital, Semarang. This research is expected to be useful as a basis for improving health services and scientific evidence for the development of nursing knowledge, especially in nursing management practices. It is also expected to enrich studies on hospital policy and human resource management related to nurses' compliance. Furthermore, it can also be inputs for the hospital regarding factors influencing nurses' compliance and become baseline data for further research on patient safety policies in the inpatient units of Dr. Kariadi hospital.

\section{METHODS}

This research was a descriptive correlational study with a cross-sectional approach. The subjects were staff nurses who worked in the inpatient units of Dr. Kariadi hospital Semarang as many as 489 (except staff nurses in Merak room as they would be used for testing the validity and reliability of the research instrument, the psychiatric unit as it did not fit the research criteria, and the Garuda Pavilion as it could not be used as a research site). A proportional random sampling technique was used to recruit the samples of 220 nurses. The data in this study were collected using a questionnaire which was developed by the researchers and had been tested for its validity and reliability. Univariate and bivariate analyses using Chi-Square test and multivariate analysis using multiple logistic regression analysis were performed for data analysis.

\section{RESULTS}

The results of this study showed that $76.8 \%$ of nurses hold the DIII/DIV education, and 23.2\% hold a bachelor/professional nursing degree. Furthermore, $54.5 \%$ of nurses had participated in the training of Six Hospital Patient Safety Goals, and the remaining $45.5 \%$ had not. The majority of nurses were female $(74.5 \%)$. Detailed characteristics of respondents in this study are presented in Table 1.

Table 2 shows that $55.5 \%$ and $44.5 \%$ of nurses perceived good supervision and poor supervi- sion related to patient safety, respectively. Around $64.1 \%$ of nurses perceived a comfortable work environment, and the remaining $35.9 \%$ perceived a less comfortable work environment. Furthermore, $65 \%$ of nurses perceived assertive authority figures, and $35 \%$ perceived less assertive authority figures. The results also showed that $86.8 \%$ of nurses perceived low, and $13.2 \%$ perceived high of contradictory orders about patient safety. Moreover, $43.6 \%$ of nurses perceived colleagues as not compliant, and $56.4 \%$ perceived colleagues as compliant. It was also found that nurses who were compliant with policies regarding patient safety were $53.2 \%$, while those who were not compliant were $46.8 \%$ (Table 3 ).

The results of the bivariate analysis using the Chi-Square test (Table 4) showed that gender $(\mathrm{p}=0.691)$, work environment $(\mathrm{p}=0.891)$, and contradictory orders $(\mathrm{p}=0.243$ ) had no effects on nurses' compliance with patient safety policies in the hospital. In contrast, supervision $(\mathrm{p}=0.038$; $\mathrm{OR}=1.828)$, characters of authority figures $(\mathrm{p}=0.001 ; \mathrm{OR}=2.648$, and non-compliant colleagues $(\mathrm{p}=0.0001 ; \mathrm{OR}=2.899)$ had effects on nurses' compliance with patient safety policies in the hospital.

The results of the multivariate analysis using a multiple logistic regression analysis showed that noncompliant colleagues had the most influence on nurses' compliance with patient safety policies in the hospital (Table 5).

\section{DISCUSSION}

\section{Level of education}

The results of the study showed that the number of nurses with DIII/DIV education is more significant than that of the S1/Ners. It is consistent with the fact that nurses with DIII education in Indonesia are more numerous than those with bachelor degree (Research and Development Team, 2010). Education indicates the process of developing various kinds of potential that exist in humans (Koesoema, 2007). Education also affects individuals' mindset, and the mindset affects one's behavior (Asmadi, 2008). Therefore, education has a vital role in increasing compliance with patient safety policies. It is consistent with a study by Anugrahini, reporting that there is a significant relationship between education level and nurses' compliance with the implementation of patient safety guidelines. However, a study by Hikmah showed that there is no relationship between education level and nurses' perceptions in the implementation of patient safety guidelines (Anugrahini, 2010). 
Table 1. Characteristics of Respondents

\begin{tabular}{lcc}
\hline Characteristics & f & \% \\
\hline Education & & \\
$\quad$ DIII/DIV & 169 & 76.8 \\
$\quad$ S1/Ners & 51 & 23.2 \\
Experiences of patient safety training & 120 & 54.5 \\
$\quad$ Yes & 100 & 45.5 \\
No & & \\
Gender & 56 & 25.5 \\
$\quad$ Male & 164 & 74.5 \\
$\quad$ Female & 220 & 100 \\
\hline Total & & \\
\hline
\end{tabular}

Table 2. Frequency Distribution of Independent Variables

\begin{tabular}{lcc}
\hline \multicolumn{1}{c}{ Independent variables } & f & \% \\
\hline Supervision & 122 & 55.5 \\
Good & 98 & 44.5 \\
Poor & & \\
Work environment & 141 & 64.1 \\
Comfortable & 79 & 35.9 \\
Uncomfortable & & \\
Characters of authority figure & 143 & 65 \\
Assertive & 77 & 35 \\
Less assertive & & \\
Contradictory orders & 29 & 13.2 \\
High & 191 & 86.8 \\
Low & & \\
Non-compliant colleagues & 124 & 56.4 \\
Compliant & 96 & 43.6 \\
Non-compliant & 220 & 100 \\
\hline Total & & \\
\hline
\end{tabular}

Table 3. Frequency Distribution of Dependent Variables

\begin{tabular}{lcc}
\hline \multicolumn{1}{c}{ Dependent variable } & f & \% \\
\hline Nurses' compliance & & \\
Compliant & 117 & 53.2 \\
Non-compliant & 103 & 46.8 \\
\hline Total & 220 & 100 \\
\hline
\end{tabular}

Table 4. Results of the Bivariate Analysis

\begin{tabular}{llc}
\hline \multicolumn{1}{c}{ Independent Variable } & Dependent Variable & p-value/OR \\
\hline Gender & Nurses' compliance & 0.691 \\
Supervision & Nurses' compliance & $0.038^{*} ;$ OR $=1.828$ \\
Work environment & Nurses' compliance & 0.891 \\
Characters of authority figures & Nurses' compliance & $0.001^{*}$ \\
Contradictory orders & Nurses' compliance & 0.243 \\
Non-compliant colleagues & Nurses' compliance & $0.0001^{*} ;$ OR $=2.899$ \\
\hline
\end{tabular}


Table 5. Results of Multiple Logistic Regression Analysis

\begin{tabular}{lllc}
\hline \multicolumn{1}{c}{ Variable } & p-value & OR & 95\% CI \\
\hline Work environment & 0.130 & 0.618 & $0.331-1.153$ \\
Characters of authority figures & 0.005 & 2.447 & $1.303-4.598$ \\
Non-compliant colleagues & $\mathbf{0 . 0 0 2}$ & 2.523 & $1.416-4.495$ \\
\hline
\end{tabular}

\section{Experiences in Training of the Six Patient Safety Goals}

The results showed that the majority of nurses at Dr. Kariadi hospital, who were the respondents of this study, had attended the training of Six Patient Safety Goals. Training is a process of transferring knowledge, expertise, and attitudes so that employees are more skilled and able to carry out their responsibilities better in accordance with the existing standards. Training refers more to the development of work skills (vocational), which can be used immediately (Mangkuprawira, 2003). A study reported that there is a relationship between training and understanding and nurses' performance in controlling nosocomial infections (Maryati, 2010). Training has several advantages. It can be held in a relatively shorter time than education and can be used immediately. Training materials can be updated immediately if there are developments, considering that patient safety standards or guidelines always develop from year to year.

\section{Gender}

The results showed that the majority of the staff nurses at Dr. Kariadi hospital, who participated in this study, were female. The nursing profession is identical to women, even though there are already male nurses. This is related to the nature of women, in which women tend to have soft tones and can be good listeners as ideal nurses are described (Bastable, 2002). Gender is one of the variables that influence behavior. However, in several studies, it is shown that stereotypes of gender differences in an organization are invalid, and there are no differences between men and women in terms of motivation and commitment (Ivancevic, 2007).

The results of the Chi-Square test showed that there was no effect of gender on nurses' compliance with patient safety policies. A study by Milgram showed that women have a higher level of compliance than men (Milgram, 1974). Similarly, a study also reported that women are more compliant in terms of obeying rules (Yagil, 2004). However, some studies showed that gender stereotypes in an organization are invalid, and there are no differences between men and women in terms of motivation and commit- ment, even though gender is one of the variables that affect behavior (Ivancevic, 2007).

\section{Supervision}

Most nurses in this study perceived that the supervision related to patient safety was relatively good. Supervision is a process to know whether the implementation of activities is following plans, guidelines, provisions, policies, goals, and targets that have been determined previously; it can be performed from within or from outside, directly or indirectly (Suarli, 2008; Muninjaya, 2004).

The results of the Chi-Square test indicated that there were effects of supervision on nurses' compliance with patient safety policies in the hospital. The analysis obtained an OR value of 1.828 , meaning that nurses who received good supervision, have 1.8 times more likely to comply with policies than those receiving poor supervision. The results of this study are consistent with a study by Kaswardani, which stated that supervision has a positive and significant effect on nurses' performance (Kaswardani, 2010).

\section{Working Environment Conditions}

The results of this study showed that most nurses perceived comfortable working environments. Nitisemito defines work environment as everything around a worker that affects him in carrying out the tasks. Sedarmayanti stated that work environment includes overall tools and materials and the surrounding environment in which a person works, his career methods, and his work arrangements both as individuals and as groups. Work environment is broadly divided into two: physical and non-physical environments (Warsito, 2006).

The result of the Chi-Square test showed that there was no effect of work environment on nurses' compliance with patient safety policies. This result is not congruent with a study by Halim, which found that work environment has a direct influence on employees (Halim, 2012).

\section{Characters of Authority Figure}

This study showed that most of the nurses perceived assertive characters of the authority fig- 
ure. Assertiveness of the authority figures is one of the characteristics of effective leadership. Ghiselli stated that the qualities of effective leadership include supervisory abilities, the need for achievement in work, intelligence, assertiveness, self-confidence, and initiative (Ivancevic, 2007).

The results of the Chi-Square test showed that there was an effect of authority figure on nurses' compliance with patient safety policies. The analysis obtained an OR value of 2.583, indicating that nurses who are supported with assertive authority figures have 2.5 times more likely to be compliant than those who have less assertive ones. The results of this study are consistent with Hartilawati's research, which reported that leaders' lack of clarity regarding work procedures negatively affects the performance and assertiveness of leaders in taking actions against employee violations that positively affect the organization performance (Hartilawati, 2009). Milgram's study found that a replacement of authority figures, i.e., from assertive figures to the less aggressive ones, will slightly affect the level of compliance of the employees (Milgram, 1974).

\section{Contradictory Orders}

The results of this study showed that nurses perceived low contradictory orders about patient safety. Contradictory orders can occur if there is no clarity about the hierarchy of authority so that the executor of the command does not have an apparent reference which actions to follow.

The results of the Chi-Square test showed that there was no effect of contradictory orders on nurses' compliance with hospital policies regarding patient safety. The results of this study are not in line with Milgram's, which stated that when two researchers give two contradictory orders, all activities will not work, as no higher authority is clearly visible, and consequently, the subjects cannot determine which actions they should follow (Milgram, 1974).

\section{Non-Compliant Colleagues}

The results of this study showed that nurses perceived low compliance of their colleagues. Kotler stated that individual behavior is affected by external factors, i.e., group attitudes and behavior. The group will give either direct and indirect influences. The group with direct influence is the one where the individual becomes a member and interacts with each other, while the group with indirect influence is the one where the individual is not a member of the group. These influences will expose individuals to certain behaviors (Rianton, 2013). The theory of planned be- havior also states that one of the factors that determine behavior is subjective norms, one of which is the influence of friends (Laksono, 2011).

The results of the Chi-Square test indicated that there is an effect of non-compliant colleagues on nurses' compliance with patient safety policies. The test obtained an OR value of 2.898, meaning that nurses who have compliant colleagues have 2.8 times more likely to comply with the policies than those who have non-compliant colleagues.

The results of this study are in line with Milgram's research, which stated that if there are two uncompliant people, the level of compliance will decrease by $10 \%$. In contrast, if there are two compliant people, the level of compliance will increase by 92.5\% (Milgram, 1974).

\section{Nurses' Compliance with Patient Safety Policies in the Hospital}

The results showed that most nurses were compliant with hospital policies related to patient safety. Compliance is part of individuals' behaviors to obey or disobey things (Maria, 2012). Nurse compliance describes nurses' behaviors towards recommendations, procedures, or regulations that should be carried out. At the compliance stage, individuals will do the advice or instructions without a willingness to carry out the actions, and they often do it as they want to avoid punishment or receive compensation (Anugrahini, 2010).

\section{CONCLUSION}

Nurses at the inpatient units of Dr. Kariadi hospital who participated in this study were mostly DIII/DIV graduates, and most of them had the experience of participating in the training of the Six Hospital Patient Safety Goals.

This study found that gender, working environment, and contradictory orders had no effects on nurses' compliance with patient safety policies in the hospital. In contrast, supervision, characters of authority figures, and non-compliant colleagues had effects on nurses' compliance with patient safety policies. Of the three factors, non-compliant colleagues gave the most influence on nurses' compliance in general.

\section{REFERENCES}

Anugrahini, Christina. 2010. Hubungan Faktor Individu dan Organisasi dengan Kepatuhan Perawat dalam Menerapkan Pedoman Pa- 
tient Safety di RSAB Harapan Kita Jakarta. Master Thesis. http://lib.ui.ac.id/ file? file=digital/20282625$\mathrm{T} \% 20$ Christine\%20Anugrahini.pdf

Asmadi. 2008. Konsep Dasar Keperawatan. Jakarta : EGC

Bastable, Susan B. 2002. Perawat sebagai Pendidik. Prinsip-Prinsip Pengajaran dan Pembelajaran. Jakarta : EGC

Halim, Sartika Hayulinda. 2012. Analisis Pengaruh Motivasi dan Lingkungan Kerja terhadap Kinerja Karyawan pada PT.Sinar Galesong Pratama Makassar. Undergraduate Thesis. https://core.ac.uk/download/pdf/ 25487678.pdf

Hartilawati. 2009. Pengaruh Kepemimpinan Transformasional terhadap Kinerja Pegawai Sub Bagian Umum di Lembaga Penjaminan Mutu Pendidikan (LPMP). http:// digilib.unila.ac.id

Ivancevic, John M, Konopaske, Robert and Matteson, Michael T. 2007. Perilaku dan Manajemen Organisasi 7th edition. Jakarta : Erlangga

Kaswardani, Meliza. 2010. Pengaruh Pengawasan dan Lingkungan Kerja terhadap Kinerja Perawat di RSUD Rokan Hulu . Pekanbaru : Riau University

Koesoema, Doni. 2007.Pendidikan Karakter, strategi Mendidik Anak di Zaman Global . Jakarta : Grasindo

Laksono, Jati Purbo. 2011. Analisis Faktor-Faktor yang Mempengaruhi Kepatuhan Wajib Pajak Badan pada Perusahaan Industri Manufaktur di Semarang . Semarang : Undergraduate Thesis. http://eprints.undip.ac.id/29806/1/ Skripsi016.pdf

Mangkuprawira, Sjafri. 2003. Manajemen Sumber Daya Manusia Strategik. 2nd Edition. Jakarta : PT Ghalia Indonesia

Maria, Ince, Kurnia, Erlin. 2012. Kepatuhan Perawat dalam Melaksanakan Standar Operasional Prosedur Pemasangan Infus terhadap Phlebitis. Journal of Stikes RS.Baptis Vol 5. No.1, page.43.

Maryati, Siti. 2011. Keefektifan Peningkatan Kemampuan Perawat dalam Pencegahan Infeksi Nosokomial pada Bayi di Ruang Neonatal Intensive Care Unit Rumah Sakit Umum Daerah Wates Kulon Progo . Thesis. https://repository.ugm.ac.id/id/eprint/ 97434

Milgram, Stanley. 1974. Obedience to Authority : An Experimental View. London: Harper \& Row
Publisher.Inc, 32-121.

Muninjaya, A,A Gde. 2004. Manajemen Kesehatan 2nd Edition. Jakarta : EGC

Pudjirahardjo, Widodo, Sopacua, Evie. 2006. Kebijakan, Sebuah Kebutuhan dalam Desentralisasi Kesehatan. Buletin Penelitian Sistem Kesehatan Pusat Penelitian dan Pengembangan Sistem Kesehatan Surabaya. Vol. 9. No. 4, page 171-73.

Research and Development Team, Ditjen DIKTI Kemdikbud. 2010. Potret Ketersediaan dan Kebutuhan Tenaga Perawat. Jakarta : Ministry of Education and Culture (Indonesia)

Rianton. 2013. Hubungan antara Konformitas Kelompok Teman Sebaya dengan Gaya Hidup Hedonis pada Mahasiswa Kab. Dhamasraya di Yogyakarta. EMPATHY Journal of Psychology Faculty Ahmad Dahlan University Vol 2 No 12013.

Rochmanadji, Widayat. 2009. Being A Great and Sustainable Hospital. Beberapa Pitfall Manajemen yang Harus Diwaspadai. Jakarta : Gramedia Pustaka Utama, 71-80.

Suarli, S and Bahtiar, Yanyan. 2008. Manajemen Keperawatan dengan Pendekatan Praktis. Jakarta : Erlangga

Sudarma, Momon. 2008. Sosiologi untuk Kesehatan. Jakarta : Salemba Medika.

Warsito, Bambang Edi. 2006. Pengaruh Persepsi Perawat Pelaksana tentang Fungsi Manajerial Kepala Ruang terhadap Pelaksanaan Manajemen Asuhan Keperawatan di Ruang rawat Inap RSJD Dr.Amino Gondohutomo Semarang. Nurse Media Journal of Nursing Vol 1 No 12007. https://ejournal.undip.ac.id/index.php/ medianers/article/view/281

Yagil. 2004. Sex Differences in Driving and Insurance Risk. s.l. : The Social and Issue 